\title{
A Rare Reason for Admission with Flank Pain: Retroperitoneal Fibrosis
}

\author{
Yan Ağrısı ile Nadir Bir Başvuru Nedeni: Retroperitoneal Fibrozis \\ Gulsah Ucan ${ }^{1}$, Mustafa Emin Canakci ${ }^{1}$, Omer Erdem Sevik ${ }^{1}$, Ruhi Cure ${ }^{1}$, Ata Ozen ${ }^{2}$ \\ ${ }^{1}$ Emergency Department, Eskisehir Osmangazi University, Eskisehir, Turkey \\ ${ }^{2}$ Urology Departmant, Eskisehir Osmangazi University, Eskisehir, Turkey
}

\section{ABSTRACT}

Retroperitoneal fibrosis (RPF) is a rare, slow progressing disease with inflammatory and fibrotic processes. The identified causes include malignancies, intra-abdominal surgeries, certain drugs, and postinfectious inflammation. However, the cause cannot be identified in most cases. It is observed twice as frequently in males. The mean age is around $50-60$ years. Fibrosis usually develops around the abdominal aorta. Ureteral compression can present with symptoms of obstructive uropathy. Surgery is the primary treatment option in patients with hydronephrosis. In this case report, we present the management of RPF which was detected by bedside ultrasonography and computed tomography (CT) imaging in a patient admitted to the emergency department with a complaint of flank pain.

Key words: Emergency department, Retroperitoneal fibrosis, Hydronephrosis

\section{INTRODUCTION}

Retroperitoneal fibrosis (RPF) is a rare, chronic disease of unknown cause, characterized by fibrosis and inflammation. Although RPF is idiopathic in two-thirds of the cases, it could also develop secondary to several factors, including the use of drugs such as ergot alkaloids, beta-blockers, aspirin, dopamine agonists, and analgesics (1). Also, infectious conditions, surgical procedures, and malignancies can cause RPF (2). The incidence of the disease is 1 per 100,000 cases. In most cases, the patients present with worsening renal function and hydronephrosis due to ureteral compression from fibrosis $(1,3)$. The majority of cases are observed after the fifth decade of life, and the male/female ratio is $2: 1$ (4).

The patient may present to the emergency department

\section{ÖZET}

Retroperitoneal fibrozis (RPF), inflamatuar ve fibrotik süreçleri olan, nadir görülen, yavaş ilerleyen bir hastalıktır. Tanımlanan nedenler arasında maligniteler, karın içi ameliyatlar, bazı ilaçlar ve enfeksiyon sonrası inflamasyon yer alır. Bununla birlikte, çoğu durumda neden tespit edilemez. Erkeklerde iki kat daha sık görülür. Ortalama yaş 50-60 yıl civarındadır. Fibrozis genellikle abdominal aort çevresinde gelişir. Üreteral kompresyon, obstrüktif üropati semptomları ile ortaya çıkabilir. Hidronefrozlu hastalarda cerrahi birincil tedavi seçeneğidir. Bu olgu sunumunda yan ağrısı şikayeti ile acil servise başvuran bir hastada yatak başı ultrasonografi ve bilgisayarlı tomografi (BT) görüntüleme ile saptanan RPF tedavisini sunuyoruz.

Anahtar Kelimeler: Acil servis, Retroperitoneal fibrozis, Hidronefroz

with symptoms of flank pain, fever, generalized weakness, and weight loss. Since the presentation can be insidious with non-specific symptoms, it can pose a diagnostic challenge to the clinician. A detailed history and exam, pertinent laboratory and imaging studies are often required to arrive at the definitive diagnosis $(5,6)$. In cases of advanced retroperitoneal fibrosis, flank pain, oliguria/anuria, hematuria, and hypertension can be observed. In this case report, we present the management strategy for a patient who was admitted to the emergency department with left flank pain, bilateral hydronephrosis, and RPF.

\section{CASE PRESENTATION}

The patient was a 68-year-old female with a history of coronary artery disease and hypertension. The patient 

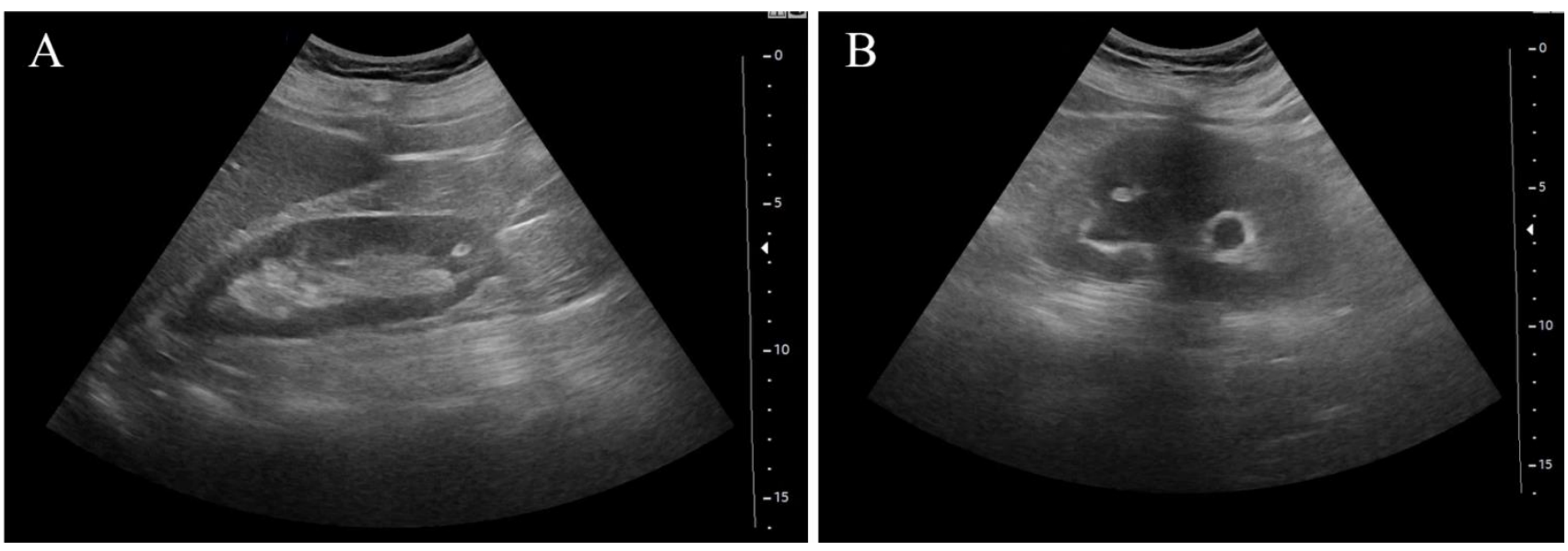

Figure 1. A) Right kidney grade 1 hydronephrosis. B) Left kidney grade 2 hydronephrosis.

was admitted to the emergency department with a complaint of left flank pain which was present for one month. The_patient did not have nausea or vomiting and the pain did not radiate to other quadrants of the abdomen. There was no history of any surgical procedure other than cholecystectomy. The patient was on metoprolol, acetylsalicylic acid, and valsartan. Vital signs were as follows: blood pressure: $116 / 70 \mathrm{mmHg}$, pulse: $65 / \mathrm{min}$, temperature: $36.5^{\circ} \mathrm{C}$, and oxygen saturation: $98 \%$. Physical examination revealed tenderness in the left upper quadrant of the abdomen. Blood urea nitrogen level was $20.8 \mathrm{mg} / \mathrm{dl}$, and creatinine level was $1.09 \mathrm{mg} / \mathrm{dl}$. Pyuria was detected in urinalysis. No other abnormalities were detected in the complete blood count, venous blood gas, and blood biochemistry results. The creatinine level of the patient was $0.74 \mathrm{mg} / \mathrm{dl}$ three months ago. The patient was evaluated by performing bedside ultrasonography, and a grade 1 chronic hydronephrosis in the right kidney and a grade 2 chronic hydronephrosis in the left kidney were detected (Figure 1). Renal parenchymas, echogenicities, and sizes were normal. Examination of the abdominal aorta showed a hyperechogenic area around the aorta (Figure 2).

CT was ordered to reveal the etiology of bilateral hydronephrosis and prolonged flank pain in the patient.
The CT scan demonstrated a $3 \times 2 \mathrm{~cm}$ mass with soft tissue density, surrounding the aorta from the infrarenal level, with enlargement toward the hilus in the proximal ureter (Figure 3). The patient was consulted with Urology, and a double-J stent was inserted in the left kidney. Post-procedure, the patient had clinical and symptomatic improvement in the following days, and was discharged.

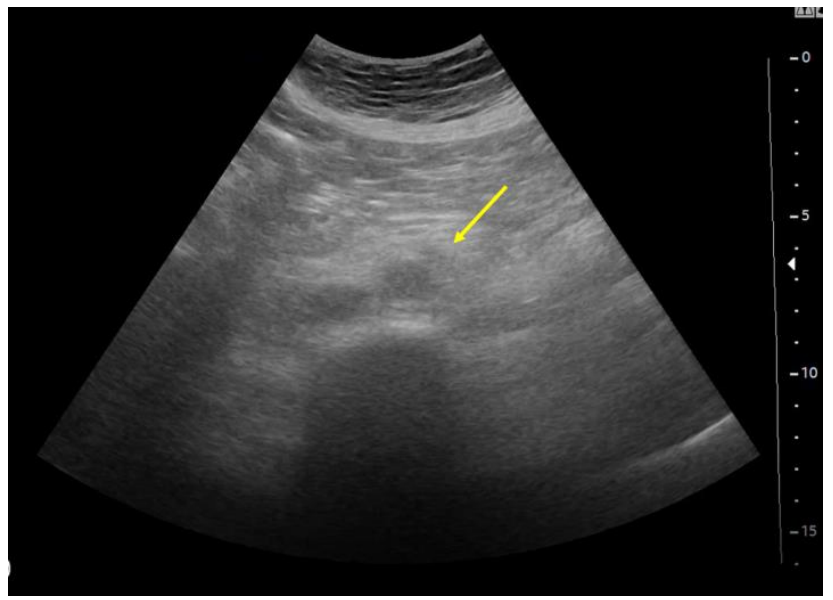

Figure 2. The hypoechogenic area around the aorta is indicated by the yellow arrow.

\section{DISCUSSION}

In literature, RPF develops using drugs such as ergot alkaloids, beta-blockers, aspirin, dopamine agonists, and analgesics (1). In etiology, infectious conditions, surgical procedures, and malignancies can cause RPF 

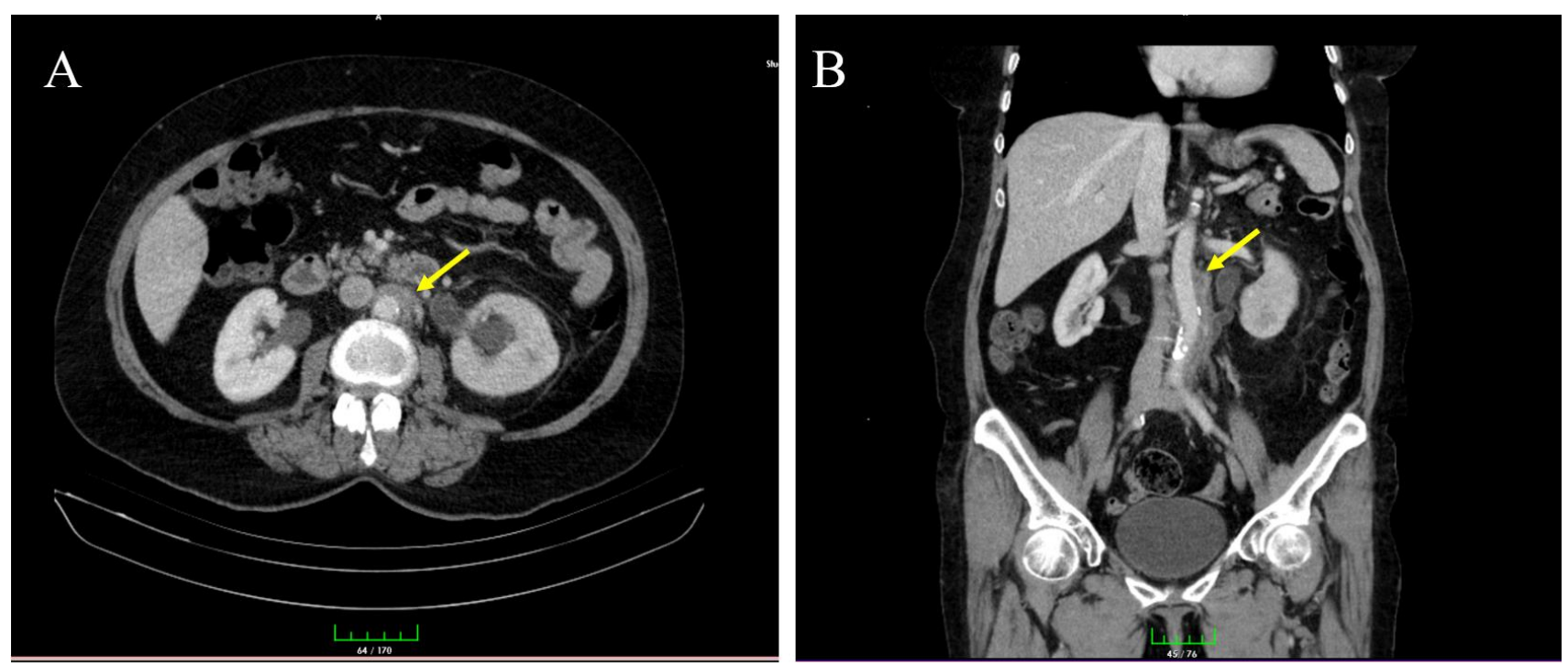

Figure 3. A) Axial plane of computerized tomography. B) Coronal plane of computerized tomography. Right kidney grade 1 ureterohydronephrosis, left kidney grade 2 hydronephrosis. Yellow arrow: Retroperitoneal fibrosis area.

(2). In our case, the patient had no history of regular use of analgesic or nonsteroidal anti-inflammatory drugs. However, use of drugs like beta-blockers and acetylsalicylic acid could be the cause RPF in our case. RPF's clinical manifestation is often characterized by the accompaniment of autoimmune disease and the presence of rigid, fibrous plaques that causes the symptoms $(7,8)$. In the absence of parenchymal damage or loss of function, patients often present with an indistinct picture and non-specific symptoms such as flank pain, weakness, and weight loss. Most cases of RPF presented with flank pain and hydronephrosis (9). These manageable symptoms might be changed into severe conditions such as anuria, uremia, and bilateral hydronephrosis. Even a case of encephalopathy developing secondary to hypertension due to RPF has been reported in the literature (10). Thankfully_our patient's presentation was limited to only an unilateral flank pain and bilateral hydronephrosis In emergency department practice, ultrasonography is an initial, noninvasive diagnostic imaging method that can be performed at the bedside in patients presenting with flank pain (11). When the etiology of flank pain is detected on ultrasound as hydronephrosis, it is a preliminary routine procedure in terms of guiding to CT for differential diagnosis in the absence of obvious causes such as kidney stones. Our patient was evaluated rapidly by performing bedside ultrasonography, and bilateral chronic hydronephrosis was detected, and we also examined the abdominal aorta that showed a hyperechogenic area around the aorta. We believe this was a turning point for our clinical decision to perform a CT scan to the precision of our diagnosis. Computed tomography is the used method in the diagnosis of retroperitoneal fibrosis. However, tissue biopsy is the gold standard for the diagnosis (12). Among the pharmacological treatment options of the disease, corticosteroid therapy alone or in combination with other immunosuppressants such as tamoxifen, azathioprine, cyclophosphamide, mycophenolate mofetil, cyclosporine, or progesterone is one of the most popular treatment methods with their antiinflammatory and anti-fibrosis effects (12). There are various recommended medical options for the treatment of RPF but none of them has significant success. Prevention of progression, recurrence, and parenchymal damage in RPF should be the primary goal of the management strategy. Ureteral stent or 
nephrostomy catheter may be placed to prevent renal damage in patients. Surgical treatment is indicated in patients with refractory disease with severe ureteral stricture or compression of main vascular structures, who are unresponsive to conservative treatment (13). RPF could develop into life threating conditions such as renal failure. In a study conducted with 155 RPF patients, $95(61.3 \%)$ of them had renal failure (14). We assume that if this patient was not diagnosed_correctly with CT scan and treated with $\mathrm{J}$ stent initially, the risk of morbidity and mortality would have been higher due to her age and the presence of comorbidities.

\section{CONCLUSIONS}

RPF is a difficult-to-diagnose condition in the emergency department because it is a rare disease, usually with chronic progression and lack of specific symptoms, laboratory tests, and a clear diagnostic algorithm. However, despite the aforementioned factors, the majority of these patients are diagnosed in emergency departments. In patients with abnormal urea concentration of unknown origin, elevation in creatinine levels, hydronephrosis, and/or ureteral deviation, RPF should be included in differential diagnoses by the emergency physician. It is crucial that the patient is quickly referred to the relevant department at the time of diagnosis to achieve a favorable clinical course and prevent irreversible pathologies.

Informed Consent: Written informed consent was obtained from the patient for publication of this case and any accompanying images.
Conflict of Interest: The authors declare they have no competing interests and no potential financial conflicts.

Funding: No funding was taken for this paper.

\section{REFERENCES}

1. Vaglio A, Salvarani C, Buzio C. Retroperitoneal fibrosis. In: Lancet. Vol 367. Lancet; 2006:241-51.

2. Ilie CP, Pemberton RJ, Tolley DA. Idiopathic retroperitoneal fibrosis: The case for nonsurgical treatment. BJU Int. 2006;98(1):137-140.

3. van Bommel EFH, Jansen I, Hendriksz TR, Aarnoudse ALHJ. Idiopathic Retroperitoneal Fibrosis. Medicine (Baltimore). 2009;88(4):193-201.

4. Yachoui R, Sehgal R, Carmichael B. Idiopathic retroperitoneal fibrosis: clinicopathologic features and outcome analysis. Clin Rheumatol. 2016;35(2):401-7.

5. Kermani TA, Crowson CS, Achenbach SJ, Luthra HS. Idiopathic retroperitoneal fibrosis: A retrospective review of clinical presentation, treatment, and outcomes. Mayo Clin Proc. 2011;86(4):297-303.

6. Caiafa RO, Vinuesa AS, Izquierdo RS, Brufau BP, Colella JRA, Molina CN. Retroperitoneal fibrosis: Role of imaging in diagnosis and follow-up. Radiographics. 2013;33(2):535-52.

7. Vaglio A, Corradi D, Manenti L, Ferretti S, Garini G, Buzio C. Evidence of autoimmunity in chronic periaortitis: A prospective study. Am J Med. 2003;114(6):454-62.

8. Katz R, Golijanin D, Pode D, Shapiro A. Primary and postoperative retroperitoneal fibrosis - Experience with 18 cases. Urology. 2002;60(5):780-3.

9. Baker LRI, Mallinson WJW, Gregory MC, et al. Idiopathic Retroperitoneal Fibrosis. A Retrospective Analysis of 60 Cases. Br J Urol. 1987;60(6):497-503.

10. Das D, Brigg J, Brown CM. Hypertensive encephalopathy in a patient with retroperitoneal fibrosis. Postgrad Med J. 1999;75(890):730-1.

11. Herbst MK, Rosenberg G, Daniels B, et al. Effect of provider experience on clinician-performed ultrasonography for hydronephrosis in patients with suspected renal colic. Ann Emerg Med. 2014;64(3):269-76.

12. Cristian S, Cristian M, Cristian P, et al. Management of idiopathic retroperitoneal fibrosis from the urologist's perspective. Ther Adv Urol. 2015;7(2):85-99.

13. Swartz RD. Idiopathic Retroperitoneal Fibrosis: A Review of the Pathogenesis and Approaches to Treatment. Am J Kidney Dis. 2009;54(3):546-53.

14. Zhao J, Li J, Zhang Z. Long-term outcomes and predict 137 large cohort of idiopathic retroperitoneal fibrosis patients: a retrospective study. Scand J Rheumatol. 2019;48(3):239-45.

Cite as: Ucan G, Canakci ME, Sevik OE, Cure R, Ozen A. A Rare Reason for Admission with Flank Pain:

Retroperitoneal Fibrosis. Eskisehir Med J. 2022;3(1):36-39. 